\title{
Kompetensi pedagogis guru dalam pembelajaran seksual pada anak autis usia remaja di Yogyakarta
}

\author{
Anis Tuing Isti Nur Syarifah, Atien Nur Chamidah \\ Jurusan Pendidikan Luar Biasa, Universitas Negeri Yogyakarta. Jalan Colombo No.1, Yogyakarta, \\ 55281, Indonesia. \\ * Corresponding Author. Email: tuingezanefa@gmail.com
}

\begin{abstract}
Abstrak: Penelitian ini bertujuan untuk mengetahui kompetensi pedagogis guru dalam pembelajaran seksual pada anak autis usia remaja di SLB Fajar Nugraha Yogyakarta. Penelitian ini merupakan penelitian deskriptif kualitatif. Data dikumpulkan dengan observasi, wawancara, dan studi dokumentasi. Analisis data dilakukan secara kualitatif yang terdiri dari mereduksi data, menyajikan data, dan membuat kesimpulan. Pemeriksaan keabsahan data dilakukan dengan menggunakan triangulasi teknik dan triangulasi sumber. Hasil penelitian menunjukkan bahwa guru melaksanakan kompetensi pedagogis dalam pembelajaran seksual anak autis usia remaja sesuai Peraturan Pemerintah Nomor 74 Tahun 2008 tentang Guru dalam Pasal 3 Ayat 4. Guru mengetahui landasan pendidikan seksual dan pentingnya pembelajaran seksual untuk anak autis. Guru juga memahami karakter anak autis usia remaja dan mengembangkan program pembelajaran seksual sesuai karakter anak autis usia remaja. Guru melaksanakan pembelajaran seksual dengan menggunakan berbagai variasi metode dan media. Guru juga memanfaatkan teknologi dalam pembelajaran seksual untuk anak autis, namun pemanfaatan teknologi elektronik belum optimal. Guru melaksanakan evaluasi dalam pembelajaran seksual dan mengembangkan perilaku seksual pada anak autis usia remaja dengan pembiasaan dalam kegiatan sehari-hari.
\end{abstract}

Kata Kunci: kompetensi pedagogis, pembelajaran seksual, autis

\section{The pedagogical competences of teacher in sexual learning for adolescents with autism at Yogyakarta}

\begin{abstract}
This study aims to know about teacher pedagogical competences in sexual learning for adolescents with autism at Fajar Nugraha Special School of Yogyakarta. This research is qualitative descriptive research. The data is collected by observation, interview, and document analysis. Data analysis in this research is qualitative analysis that contains data reduction, data display, and verification. The data validity in this research is technical triangulation and sources triangulation. The result of this research shows that subjects understand and implement the pedagogical competences in sexual learning for adolescents with autism that is accordance with The Regulation of Government 74 Year 2008 Abour Teacher, Article 3, Verse 4. The teachers know the foundation and importance of sexual learning for autism. The teachers know characteristics of adolescents with autism and develop the sexual learning program according to the characteristics of adolescents with autism. The teachers use various methods and medias in sexual learning. The teachers also use the technology in sexual learning for adolescent with autism, but using electronical technology hasn't be optimized. The teachers evaluate the results learning from sexual learning and develop sexual behavior to adolescent with autism by habituation in daily life.
\end{abstract}

Keyword: pedagogical competence, sexual learning, autism

\section{PENDAHULUAN}

Guru merupakan elemen penting dalam proses pendidikan. Posisi guru sangat strategis, yang keberadaannya mempengaruhi kualitas pendidikan, baik dari segi proses hingga hasil pendidikan tersebut. Guru berada pada garda terdepan dalam menciptakan pendidikan yang sukses dan mengembangkan kompetensi sumber daya manusia. Di tangan guru dihasilkan peserta didik yang berkualitas, baik secara akademis, skill (keahlian), kematangan emosional, moral dan spiritual (Marwiyah, 2012: 50). Muhson (2004: 91) juga mengungkapkan bahwa keberhasilan proses pendidikan dapat dikatakan sangat tergantung pada peran guru di sekolah. Oleh karena itu, posisi guru sangat berpengaruh dalam menentukan kualitas suatu pendidikan. 


\title{
JPK (J urnal Pendidikan Khusus), 14 (2), 2018 - 87
}

\author{
Anis Tuing Isti Nur Syarifah
}

Guru perlu melakukan pekerjaan mendidiknya dengan profesional agar dapat mewujudkan halhal tersebut. Guru berkualitas adalah guru yang profesional dengan profesi mengajarnya. Menjadi guru profesional diperlukan memenuhi kualifikasi dan menguasai kompetensi (Payong, 2011: 16). Profesionalitas guru diketahui dengan tingkat penguasaan guru terhadap kualifikasi dan kompetensi yang ada. Terdapat beberapa kompetensi yang perlu dikuasai oleh guru, salah satunya adalah kompetensi pedagogis.

Kompetensi pedagogis berkaitan dengan kemampuan guru untuk mengatur pengetahuan pembelajaran, dimulai dari perencanaan hingga evaluasi. Dalam Undang-Undang Nomor 14 Tahun 2005 tentang Guru dan Dosen dalam Pasal 10 Ayat 2, kompetensi pedagogis merupakan kemampuan mengelola pembelajaran peserta didik. Guru perlu menguasai kompetensi pedagogis agar dapat menjalankan kegiatan pembelajaran secara terarah. Payong (2011: 29) menyatakan bahwa kompetensi pedagogis nampaknya merupakan kompetensi yang tertua dan bahkan sudah menjadi tuntunan mutlak bagi manusia sepanjang zaman. Artinya bahwa kompetensi pedagogis merupakan kompetensi paling pokok diantara kompetensi-kompetensi lainnya.

Peraturan Pemerintah Nomor 19 Tahun 2005 tentang Standar Nasional Pendidikan dalam Pasal 28 Ayat 3 menguraikan bahwa kompetensi pedagogis mencakup pemahaman wawasan atau landasan kependidikan, pemahaman tentang peserta didik, pengembangan kurikulum, perancangan pembelajaran, pelaksanaan pembelajaran yang mendidik dan dialogis, evaluasi hasil belajar, dan pengembangan peserta didik untuk mengaktualisasikan berbagai potensi yang dimilikinya. Kompetensi ini mencakup tentang cara guru memperkaya diri dengan wawasan pendidikan sebagai bekal mendidik dan mengaplikasikannya dalam kegiatan belajar mengajar.

Kompetensi pedagogis guru penting dalam mengajar peserta didik, termasuk peserta didik autis. Peserta didik autis membutuhkan berbagai pendidikan, termasuk pendidikan seksual bagi anak autis yang sudah memasuki usia remaja. Menurut Voss dalam Wuryani (2008: 5-6), tujuan pendidikan seksual yaitu memberikan informasi yang tepat dan mengurangi mitos dan konsepsi yang keliru, menunjukkan sikap toleransi dan membantu partisipan agar menerima orang lain dengan pandangan dan tingkah laku yang berbeda, menunjukkan pemecahan masalah sosial, dan merupakan komunikasi yang terbuka dan memudahkan hubungan antara orang-orang yang berjenis kelamin berbeda.

Anak autis usia remaja memiliki perkembangan yang sama dengan remaja pada umumnya. Sebuah penelitian terhadap 131 individu autis di Kanada mengungkapkan bahwa individu autis memiliki tingkat perkembangan seksual yang sama dengan individu pada umumnya (Henault, 2013: 1). Aziz (2014: 184) menjelaskan bahwa anak berkebutuhan khusus pada prinsipnya memiliki perkembangan dorongan seksual yang sama dengan anak-anak umumnya. Di sisi lain, hambatanhambatan yang dialami anak autis berpengaruh buruk dalam pemahaman terhadap perubahan dirinya yang mengalami masa remaja. American Psychiatric Association (2013: 50) mengungkapkan bahwa anak autis sulit untuk melakukan komunikasi timbal balik dan menggunakan bahasa komunikasi non verbal, memiliki pola perilaku yang terbatas yaitu sangat terikat dengan rutinitas, dan sulit menerima perubahan. Oleh karena itu, anak autis sulit untuk menerima informasi-informasi, khususnya tentang perkembangan seksual dirinya. Beberapa anak autis sulit untuk menerima perubahan fisik yang dialami. Mereka merasa tidak nyaman dan tertekan dengan perubahan yang dialami dan tidak bisa mereka hilangkan, sehingga berujung pada emosi yang meledak-ledak dan tantrum.

Guru anak autis perlu memperhatikan hal ini dengan memberikan pendidikan seksual yang tepat. Aziz (2014: 182) menjelaskan bahwa pendidikan seksual merupakan upaya preventif agar setiap anak berkebutuhan khusus dapat mengelola perubahan secara biologis pada dirinya, menghargai perilaku seks orang lain, serta tidak terjebak pada perilaku seks yang menyimpang atau mendapatkan kekerasan dan pelecehan seksual dari orang lain. Pelaksanaan pendidikan seksual kepada anak autis hendaknya dilakukan secara menyeluruh, baik dalam lingkungan sekolah maupun rumah.

Seperti yang telah diuraikan sebelumnya bahwa pelaksanaan pendidikan seksual di lingkungan sekolah memerlukan guru profesional untuk mengajarkannya. Guru perlu menguasai kompetensi pedagogis guru yang ada. Kompetensi pedagogis menjadi ukuran kesiapan seorang guru dalam melaksanakan pendidikan seksual. Dalam National Teacher Preparation Standards for Sexuality Education (SIECUS, 2010: 3), dijelaskan bahwa guru perlu memenuhi standar tertentu dalam melaksanakan pendidikan seksual untuk remaja, yaitu memahami pengetahuan, memahami kode etik pengajaran, memahami perbedaan dan persamaan, perencanaan pembelajaran, implementasi, dan 


\title{
J PK (J urnal Pendidikan Khusus), 14 (2), 2018 - 88
}

\author{
Anis Tuing Isti Nur Syarifah
}

asesmen. Timmerman (2009: 505) juga menjelaskan berdasarkan penelitiannya, bahwa perilaku mengajar dan teknik mengajar sangat berpengaruh dalam pembelajaran seksual pada peserta didik. Dari beberapa uraian tersebut, dapat dipahami bahwa kompetensi pedagogis sangat penting dikuasai guru dalam pendidikan seksual. Kompetensi pedagogis menjadi bekal guru dalam menentukan ide dan program pembelajaran yang tepat untuk peserta didik, khususnya untuk anak autis usia remaja.

Berdasarkan observasi awal di beberapa sekolah luar biasa pada bulan Agustus sampai September 2017, beberapa guru belum menerapkan pembelajaran khusus mengenai pendidikan seksual pada anak autis, baik dari rancangan pembelajaran hingga proses pengembangan perilaku seksual yang sesuai secara lebih lanjut. Guru hanya mengajarkan materi seksualitas secara insidental. Hal ini diketahui dengan tidak adanya catatan atau dokumen program pembelajaran yang mencakup pembelajaran seksual. Selain itu, dalam pembelajaran, guru sangat jarang menyinggung mengenai perkembangan yang dialami anak autis usia remaja. Bahkan ketika anak autis usia remaja melakukan perilaku seksual yang tidak sesuai, beberapa guru menegur dengan keras atau membiarkan anak melakukan hal tersebut di jam-jam tertentu. Guru membiarkan anak autis melakukan perilaku seksual tersebut tanpa memberikan pemahaman kepada anak tentang perilaku seksual yang seharusnya dilakukan anak autis tersebut.

Peneliti juga melakukan observasi awal pada bulan Februari 2018 di SLB Fajar Nugraha. SLB Fajar Nugraha merupakan salah satu sekolah luar biasa yang melaksanakan pendidikan khusus untuk anak autis saja. Berdasarkan hasil penelitian, ditemukan bahwa guru SLB Fajar Nugraha memberikan perhatian yang lebih baik dalam pendidikan seksual pada anak autis dibanding dengan guru di sekolah lain. Hal ini dapat diketahui dengan adanya dokumen tentang program pembelajaran seksual yang terintegrasi dengan pembelajaran lain. Selain itu, guru juga mengajarkan tentang perkembangan fisik yang dialami anak autis dan konsekuensi perilaku yang harus dilakukan, seperti mengajarkan bahwa anak memiliki jerawat dan bagaimana cara menyikapinya. Guru juga mengajarkan beberapa hal tentang materi seksualitas sejak dini, seperti membiasakan anak perempuan untuk memakai pembalut. Pihak sekolah juga memberikan perhatian kepada setiap guru dengan memfasilitasi guru untuk mengikuti pelatihan Kesehatan Reproduksi yang diadakan oleh pemerintah. Hal-hal tersebut tidak terlepas dari kompetensi pedagogis yang harus dikuasai oleh guru.

Berdasarkan hal tersebut, peneliti tertarik untuk mengetahui secara lebih lanjut mengenai kompetensi pedagogis guru dalam pembelajaran seksual pada anak autis usia remaja di SLB Fajar Nugraha Yogyakarta.

\section{METODE PENELITIAN}

\section{Pendekatan Penelitian}

Jenis penelitian yang digunakan adalah penelitian dekriptif dengan pendekatan kualitatif. Menurut Moleong (2007: 8), penelitian kualitatif adalah penelitian yang bermaksud untuk memahami fenomena tentang apa, yang dialami oleh subjek penelitian, misalnya perilaku, persepsi, motivasi, tindakan, dan lainnya; secara holistik dan dengan cara deskripsi dalam bentuk kata-kata dan bahasa, pada suatu konteks khusus yang alamiah dan dengan memanfaatkan berbagai metode alamiah.

Penelitian ini menggunakan jenis penelitian deskriptif kualitatif mengetahui gambaran yang ada melalui pengumpulan informasi yang lengkap mengenai kompetensi pedagogis guru dalam pembelajaran seksual pada anak autis usia remaja di SLB Fajar Nugraha Yogyakarta.

\section{Setting Penelitian}

Penelitian ini dilaksanakan di SLB Fajar Nugraha Yogyakarta yang beralamat di Jl. Seturan II no. 59 Caturtunggal Depok Sleman Yogyakarta. Adapun penelitian dilaksanakan selama 6 bulan, yaitu Februari-Juli 2018.

\section{Sumber Data}

Sumber data dalam penelitian ini yaitu guru di SLB Fajar Nugraha yang sedang mengampu pembelajaran pada anak autis usia remaja. Berdasarkan hal tersebut, didapatkan dua guru yang keduanya bekerjasama mengampu pembelajaran anak autis usia remaja. Dua orang guru tersebut berinisial SY dan MR. Keduanya bekerjasama mengampu 3 anak autis usia remaja.

Selain itu, sumber data penelitian ini juga didapatkan dari kepala sekolah. Data dari kepala sekolah digunakan untuk menguatkan informasi yang telah didapatkan dari guru, sehingga didapatkan data yang lengkap dan valid. Kepala sekolah SLB Fajar Nugraha Yogyakarta berinisial YEA. YEA 
telah menjadi kepala sekolah di SLB Fajar Nugraha selama satu tahun ini.

\section{Metode dan Instrumen Pengumpulan Data}

Metode atau teknik pengumpulan data yang digunakan dalam penelitian ini yaitu wawancara, observasi, dan studi dokumentasi.

Wawancara dalam penelitian ini menggunakan teknik wawancara mendalam (in-depth interview) dimana peneliti mengajukan pertanyaan terhadap kepala sekolah dan guru anak autis usia remaja, kemudian narasumber memberikan jawaban secara rinci dan lengkap. Instrumen yang digunakan adalah pedoman wawancara yang memuat pertanyaan-pertanyaan tertentu sesuai dengan indikator tentang kompetensi pedagogis guru dalam pembelajaran seksual.

Observasi dalam penelitian ini menggunakan teknik observasi partisipasi pasif, dimana peneliti melakukan pengamatan terhadap kegiatan guru selama proses pembelajaran tanpa terlibat dalam kegiatan tersebut. Instrumen yang digunakan yaitu pedoman observasi berupa checklist dengan deskripsi narasi singkat. Indikator dalam instrumen ini sesuai aspek kompetensi pedagogis guru dalam pembelajaran seksual.

Studi dokumentasi dalam penelitian ini dilakukan dengan menganalisis arsip asesmen peserta didik, arsip program pembelajaran seksual, lembar evaluasi pembelajaran seksual. Instrumen yang digunakan yaitu pedoman analisis dokumen berupa checklist dan deskripsi narasi singkat. Indikator dalam instrumen ini sesuai dengan muatan kompetensi pedagogis guru dalam pembelajaran seksual.

\section{Keabsahan Data}

Teknik keabsahan data yang digunakan dalam penelitian ini adalah triangulasi dengan model triangulasi teknik dan triangulasi sumber. Triangulasi teknik dalam penelitian ini dilakukan dengan cara peneliti membandingkan data antara data hasil wawancara guru, hasil observasi, dan hasil studi dokumentasi, agar didapatkan data yang valid. Adapun triangulasi sumber dilakukan dengan membandingkan hasil wawancara dengan guru dan hasil wawancara dengan kepala sekolah, sehingga didapatkan data yang valid mengenai kompetensi pedagogis guru dalam pembelajaran seksual anak autis usia remaja di SLB Fajar Nugraha Yogyakarta.

\section{Analisis Data}

Analisis data dalam penelitian ini merujuk pada teknik analisis data kualitatif menggunakan mode Miles \& Huberman (Sugiyono, 2014: 338), yaitu:

1. Data reduction (Reduksi data)

Peneliti mengorganisir data dengan memilih hal yang pokok dan memfokuskan pada hal yang penting, sehingga data benar-benar memberikan gambaran tentang kompetensi pedagogis guru dalam pembelajaran seksual anak autis usia remaja di SLB Fajar Nugraha Yogyakarta.

2. Data display (Penyajian Data)

Penyajian data dalam penelitian ini berupa uraian singkat yang berbentuk teks naratif untuk mendeskripsikan hasil penelitian mengenai kompetensi pedagogis guru dalam pembelajaran seksual anak autis usia remaja di SLB Fajar Nugraha Yogyakarta.

3. Verification (Kesimpulan/verifikasi)

Kesimpulan awal dalam penelitian ini masih bersifat sementara. Untuk menguatkan kesimpulan tersebut dan menjadi kesimpulan kredibel, peneliti melakukan verifikasi dengan mengkonsultasikan pada Dosen pembimbing, bertukar pikiran dengan teman, dan melakukan triangulasi dalam teknik pengumpulan data dan sumber data.

\section{HASIL PENELITIAN DAN PEMBAHASAN}

\section{Hasil Penelitian}

\section{Deskripsi pemahaman wawasan atau landasan kependidikan}

Berdasarkan hasil pengumpulan data melalui berbagai teknik, dapat diketahui bahwa SY dan MR tidak memahami sepenuhnya tentang landasan yuridis, pedagogis, dan filosofis dalam pendidikan seksual anak autis remaja. Namun, YEA sebagai kepala sekolah menguatkan bahwa sebenarnya guru memahami landasan tersebut, hanya saja hal tersebut tidak menjadi perhatian utama dan lebih memperhatikan tingkat kemampuan belajar anak autis usia remaja.

SY dan MR juga menyadari pendidikan seksual penting untuk anak autis, yaitu mengarahkan perilaku anak terarah dan sesuai dengan norma yang ada di masyarakat, tidak melakukan perilaku seksual yang tidak sesuai, dan mampu mengatur kebersihan dirinya dengan baik. Secara rinci, hal 


\title{
J PK (J urnal Pendidikan Khusus), 14 (2), 2018 - 90
}

\author{
Anis Tuing Isti Nur Syarifah
}

tersebut disampaikan kedua subjek.

MR: "Penting sih sebenarnya, apalgi untuk anak-anak yang memasuki pubertas... Takutnya nanti dia ke orang lain melakukan hal itu. Jadi kita kasih batasan."

SY: "Pendidikan seksual untuk anak autis perlu karena dilihat dari karakteristik mereka dari segi kontrol mereka tidak punya, inisiatif masih harus dibiasakan, dan ketika anak tidak paham terutama tentang gejala-gejala seksualitas yang dialami anak, akan merugikan dirinya sendiri dan orang lain.”

Dalam pembelajaran seksual, SY dan MR menerapkan teori behavior atau teori belajar perilaku. Hal ini diketahui dengan adanya reward dan punishment yang diberikan sesuai dengan penguasaan anak autis terhadap perilaku yang diharapkan, serta adanya perancangan keterampilan-ketrampilan tertentu untuk membentuk suatu perilaku yang utuh. SY dan MR menentukan strategi pembelajaran sesuai dengan karakter dan kemampuan belajar anak autis usia remaja. Adapun berkaitan dengan kompetensi dan materi ajar, kedua subjek melakukan modifikasi yang sesuai dengan tingkat kemampuan belajar anak autis usia remaja. Hal ini disampaikan secara lebih rinci oleh SY.

SY: "kita melakukan modifikasi kurikulum dengan mengambil bagian kurikulum yang cocok, jadi bisa kelas 1 dipakai untuk kelas 6. Dinas sudah semaksimal mungkin untuk membuat kurikulum secara fleksibel. Bisa dimodifikasi, substitusi, grade nya bisa diturunkan atau dinaikkan.”

\section{Deskripsi pemahaman terhadap peserta didik}

Berdasarkan hasil penelitian, SY dan MR memahami kondisi anak autis, baik dalam perkembangan fisik, intelektual, dan sosial-emosional. Kedua subjek mengetahui kondisi fisik anak autis melalui pengamatan terhadap anak, sejak anak kecil sampai saat ini. Kedua subjek juga mengetahui tingkat intelektual dan sosial-emosional anak autis melalui asesmen awal, keterangan orangtua, hasil pembelajaran seksual, dan pengamatan sehari-hari

SY dan MR juga mengidentifikasi karakter belajar anak, melalui pengamatan sehari-hari dan hasil asesmen awal. Di sisi lain, saat anak mengalami kesulitan belajar, SY dan MR membantu anak autis dengan memberikan bantuan berupa pengulangan intruksi, bantuan dengan contoh, bantuan isyarat, atau bantuan fisik.

Aspek lain yang perlu diketahui dalam pemahaman peserta didik yaitu mengidentifikasi kemampuan/ pemahaman awal anak autis usia remaja tentang seksualitas. SY dan MR mengidentifikasi hal tersebut melalui hasil asesmen, pengamatan sehari-hari, dan pengukuran dengan pemberian materi dasar dalam pembelajaran seksual.

SY dan MR juga berusaha memberikan hak belajar seksual anak autis yang sama dengan remaja lainnya; dengan mempertimbangkan tingkat kemampuan belajar anak autis usia remaja. Kedua subjek juga melakukan kegiatan sosialisasi ke tempat umum agar anak mengetahui secara lebih jelas tentang norma seksual yang berlaku dalam masyarakat. Hal tersebut dapat diketahui dari salah satu hasil wawancara di bawah ini.

SY : “... Karena masih tahap awal: identifikasi anggota tubuh, cara merawat. Baru sampai seperti itu. Kalau di kelas.”

"Kita juga mengaplikasikan kemampuan anak ke program sosialisasi. Misalnya, anak di tempat umum tidak boleh seperti ini, harus seperti ini. Atau ini yang perempuan, ini yang laki-laki."

\section{Deskripsi pengembangan kurikulum dan perancangan pembelajaran}

SY dan MR melakukan identifikasi kebutuhan belajar sebelum menentukan rancangan pembelajaran seksual. Identifikasi kebutuhan belajar seksual di sekolah ini terbagi menjadi dua, yaitu identifikasi untuk anak baru dan identifikasi untuk anak yang sudah menjadi murid di sekolah tersebut. Identifikasi kebutuhan belajar untuk anak baru dilakukan oleh tim guru dan mengamati topik-topik yang termuat dalam form asesmen. Adapun identifikasi kebutuhan belajar untuk anak yang sudah menjadi murid di sekolah tersebut, dilakukan oleh kedua subjek secara pribadi dengan menggali informasi dari hasil pembelajaran sebelumnya, informasi orangtua, dan guru lainnya.

SY dan MR merumuskan kompetensi pembelajaran seksual berdasarkan kemampuan dan keterbatasan anak autis usia remaja yang diketahui melalui asesmen. Setiap kompetensi dirancang dalam keterampilan-keterampilan untuk membentuk satu keutuhan perilaku.

Setelah merumuskan kompetensi, SY dan MR menyusun silabus berdasarkan modifikasi 


\title{
J PK (J urnal Pendidikan Khusus), 14 (2), 2018 - 91
}

\author{
Anis Tuing Isti Nur Syarifah
}

kurikulum yang telah dilakukan. Kurikulum dari pemerintah dimodifikasi sesuai dengan kemampuan belajar anak autis usia remaja.

SY dan MR juga merumuskan tujuan pembelajaran seksual untuk anak autis usia remaja. Kedua subjek merancang tujuan pembelajaran sesuai kemampuan awal anak autis, sejauh mana kemampuan anak dapat dikembangkan, dan pertimbangan dari orangtua. SY dan MR menjelaskan dalam uraian berikut ini.

SY: "Goalnya apa dalam mengajarkan anak. ... Anak itu seberapa kemampuannya, dan saya mau mengarahkan anak ini kemana."

MR: "Berdasarkan ke kemampuan dasar anak seperti apa. Jadi yang sekiranya anak mampu untuk mencapai. Saya juga konsultasikan ke orangtua. Saya kasih rancangan program atau RPP, dan saya sampaikan ke orangtua...”

SY dan MR mengembangkan silabus dalam bentuk RPP. RPP disusun sesuai dengan silabus. RPP yang dibuat memuat komponen-komponen, yaitu KI-KD, indikator, tujuan pembelajaran, media dan sumber belajar, materi pembelajaran, metode, langkah pembelajaran, dan rancangan penilaian.

Adapun materi pembelajaran seksual yang dirancang oleh SY dan MR adalah identifikasi anggota tubuh dan kebersihan diri. Materi tersebut bersifat terkini, sesuai usia dan kemampuan anak autis usia remaha, dapat dilaksanakan di kelas, dan sesuai dengan konteks kehidupan sehari-hari.

\section{Deskripsi pelaksanaan pembelajaran yang mendidik dan dialogis}

Inti dari proses pendidikan adalah pelaksanaan pembelajaran itu sendiri. SY dan MR melaksanakan pembelajaran seksual seusia dengan rancangan sebatas pada tujuan pembelajaran. Adapun dalam hal teknis seperti langkah pembelajaran dan penerapan metode-media, kedua subjek menyesuaikan dengan kondisi anak yang mudah berubah. Selain itu, SY dan MR melaksanakan pembelajaran seksual yang berfungsi membantu anak autis agar dapat memahami materi, bukan untuk menguji. Bantuan yang diberikan adalah pemberian variasi metode dan media, pengenalan anak terhadap perkembangan fisik dirinya dan konsekuensinya, serta pemberian materi dari yang paling sederhana. Bantuan lain yang diberikan kedua subjek yaitu pengulangan intruksi, bantuan isyarat, bantuan fisik, dan pemberian contoh; yang diberikan saat anak mengalami kesulitan dalam memahami materi pembelajaran seksual.

SY dan MR menyampaikan materi pembelajaran berdasarkan tingkat kemampuan belajar anak autis usia remaja. Hal tentang perkembangan fisik anak yang menonjol, disampaikan saat tertentu dan tidak termuat dalam rancangan pembelajaran.

Adapun hal yang dilakukan SY dan MR saat menjumpai anak autis usia remaja melakukan perilaku seksual yang tidak sesuai yaitu memberikan teguran tegas (kadang diiringi dengan teguran fisik secara pelan), teguran berulang, meminta anak untuk mandi saat ereksi, meningkatkan pengamatan, dan memperbanyak aktivitas belajar anak autis usia remaja.

SY dan MR melaksanakan pembelajaran seksual sesuai dengan kurikulum yang sudah dimodifikasi, tingkat kemampuan belajar anak, dan konteks kehidupan sehari-hari. Contoh pembelajaran seksual yang dikaitkan dengan kehidupan sehari-hari yaitu mengidentifikasi anggota tubuhnya dalam kegiatan mandi.

Poin lain yang termuat dalam aspek ini yaitu melakukan pembelajaran seksual yang bervariasi. SY dan MR melakukan variasi dalam pelaksanaan pembelajaran seksual, yaitu dengan pengunaan media dan metode, tempat pembelajaran, serta pemberian materi pembelajaran yang beragam dan tidak terpaku pada satu materi tertentu. Kedua subjek melaksanakan pembelajaran tidak selau sesuai dengan waktu yang direncanakan, namun menyesuaikan dengan kondisi anak autis usia remaja saat itu.

Guru yang baik seharusnya mampu untuk fokus selama pembelajaran seksual berlangsung dan tidak sibuk dengan kegiatan pribadinya. SY dan MR tidak melakukan aktivitas di luar kepentingan pembelajaran saat proses pembelajaran berlangsung. Jika ada kegiatan di luar kebutuhan pembelajaran seksual, aktivitas tersebut berkaitan dengan kepentingan sekolah, Dinas Pendidikan, atau perintah dari kepala sekolah.

Agar pembelajaran lebih bermakna, guru perlu melibatkan anak autis secara aktif dalam pembelajaran seksual. SY dan MR melibatkan anak autis secara aktif dalam pembelajaran seksual dengan membuat variasi pembelajaran yang nyaman dan menyenangkan. Variasi yang dilakukan yaitu dalam penggunaan media dan metode, tempat pembelajaran, dan pemberian materi pembelajaran yang 


\title{
J PK (J urnal Pendidikan Khusus), 14 (2), 2018 - 92
}

\author{
Anis Tuing Isti Nur Syarifah
}

beragam serta tidak terpaku pada satu materi tertentu. Cara lain yang dilakukan untuk melibatkan anak autis agar aktif adalah dengan pemberian intruksi yang menuntut anak untuk memberikan respon.

\section{Deskripsi pemanfaatan teknologi pembelajaran}

Berdasarkan hasil penelitian, SY dan MR menggunakan berbagai media dalam pembelajaran seksual untuk anak autis usia remaja, yaitu media kartu dan benda-benda nyata yang digunakan dalam kegiatan praktek. Kedua subjek sebenarnya memiliki video yang dapat digunakan untuk pembelajaran seksual, hanya saja jarang digunakan, karena penggunaan video sering berpengaruh buruk terhadap mood belajar anak autis usia remaja.

Adapun media internet belum digunakan sebagai sumber belajar dalam pembelajaran seksual di sekolah ini. Internet lebih optimal digunakan dalam pembelajaran lainnya. SY dan MR menyampaikan bahwa penggunaan media saat ini (kartu dan benda-benda nyata) dirasa cukup untuk membantu penyampaian materi pembelajaran seksual kepada anak autis usia remaja. Hal ini dikuatkan dengan pernyataan dari YEA sebagai informan.

YEA: "Masih belum optimal si mba, kalau pendidikan seksual. Kalau identifikasi tubuh, kita coba pakai internet, dengan video yang ada di internet. Ya iu video identifikasi tubuh. Soalnya, kita lebih banyak pakai media yang ada, kayak kartu atau benda nyata.”

\section{Deksripsi evaluasi hasil belajar}

SY dan MR menyusun alat/ instrumen penilaian yang digunakan dalam kegiatan evaluasi pembelajaran seksual, yang berupa form pengamatan dengan beberapa indikator penilaian tertentu. Berikut penjelasan SY dan MR kepada peneliti.

MR: "Di RPP sudah ada. Di setiap penilaiannya ada 4 kategori. Mandiri, mandiri dengan instruksi, dengan bantuan, dan belum mampu. Ukuran perilaku didapatkan dengan pengamatan..."

SY: "Kalau disini, yang saya pakai lebih ke pengamatan. Dari pengamatan itu, langsung saya cari di bagian mana yang belum maksimal.... Evaluasi ketika ada kesalahan dan mengalami kesulitan, langsung saya benahi. Kemudian di konversi sesuai yang di RPP.”

SY dan MR juga melakukan analisis terhadap hasil penilaian berupa analisis deskriptif yang ditulis dalam narasi singkat. Analisis hasil penilaian menjelaskan tentang kemampuan yang sudah berkembang, kemampuan yang perlu dikembangkan, dan hal yang di luar kemampuan anak autis usia remaja. Selain itu, SY dan MR tidak melakukan kegiatan remedial dan pengayaan dalam pembelajaran seksual. Hal ini dikarenakan kedua subjek langsung mengatasi kesulitan anak autis saat anak mengalami kesulitna dan segera mengembangkan ke kegiatan selanjutnya ketika anak menunjukkan kemajuan dalam pembelajaran seksual.

Setelah melakukan analisis penilaian, SY dan MR memanfaatkan hasil analisis tersebut sebagai bahan penyusunan rancangan pembelajaran seksual selanjutnya. Hasil penilaian juga melengkapi informasi mengenai anak, jika informasi dari guru pengampu sebelumnya kurang lengkap.

SY dan MR menggunakan beberapa teknik dalam pembelajaran seksual yaitu pengamatan perkembangan perilaku yang dilakukan dalam kegiatan sehari-hari dan dalam kegiatanunjuk kerja. Kedua subjek melaksanakan evaluasi pembelajaran selama setiap hari dan dicatat dalam buku penghubung. Evaluasi tersebut dirangkum selama tiga bulan sekali dan setiap akhir semester dalam laporan khusus.

\section{Deskripsi pengembangan perilaku seksual yang sesuai pada peserta didik}

Dalam pengembangan perilaku seksual pada anak autis usia remaja, SY dan MR melakukan beberapa hal. SY dan MR melakukan analisis hasil pembelajaran seksual untu mengetahui tingkat kemajuan anak autis dalam pembelajaran seksual. Selain itu, SY dan MR memfasilitasi pembelajaran seksual yang sesuai dengan cara belajar anak, yaitu dengan melakukan variasi metode, media, dan setting pembelajaran.

SY dan MR mengidentifikasi kemampuan dan keterbatasan anak autis dalam pembelajaran seksual melalui pengamatan sehari-hari, asesmen, dan hasil pembelajaran. Hasil identifikasi tersebut dapat bermanfaat untuk mengembangkan program pembelajaran selanjutnya.

Diperlukan perhatian guru dan kemampuan guru membangun interaksi dan motivasi dalam pembelajaran seksual anak autis. SY dan MR memberikan perhatian kepada anak autis melalui pengamatan sehari-hari, melaksanakan pembelajaran seksual yang menyenangkan, dan segera memberikan bantuan saat anak mengalami kesulitan. Adapun interaksi dan motivasi dibangun SY dan MR dengan beberapa cara. SY membangun hal tersebut dengan pemberian reward, pembiasaan 


\title{
J PK (J urnal Pendidikan Khusus), 14 (2), 2018 - 93
}

\author{
Anis Tuing Isti Nur Syarifah
}

perilaku, dan pemberian materi dengan intruksi. Dan MR membangun hal tersebut dengan membuat pembelajaran yang menyenangkan dan bervariasi; serta pemberian materi dengan intruksi.

\section{Pembahasan}

Pembelajaran seksual mengajarkan anak autis untuk memahami perkembangan dirinya dan konsekuensinya, serta berperilaku seksual sesuai dengan norma masyarakat. Untuk mewujudkan pendidikan seksual yang berkualitas, guru anak autis dituntut menjadi guru yang profesional. Guru profesional harus menguasai kompetensi-kompetensi yang ada, karena kompetensi menjadi kualifikasi persyaratan profesionalisme guru (Siswoyo, 2013: 117). Salah satu kompetensi yang perlu dikuasai adalah kompetensi pedagogis.

Guru anak autis perlu menguasai kompetensi pedagogis guna melaksanakan pembelajaran seksual berkualitas. Aspek dalam kompetensi pedagogis guru termuat dalam Peraturan Pemerintah Nomor 74 tahun 2008 tentang Guru Pasal 3 Ayat 4, yaitu pemahaman wawasan atau landasan kependidikan, pemahaman terhadap peserta didik, pengembangan kurikulum dan perancangan pembelajaran, pelaksanaan pembelajaran yang mendidik dan dialogis, pemanfaatan teknologi pembelajaran, evaluasi hasil belajar, dan pengembangan potensi peserta didik.

Aspek pertama adalah pemahaman guru terhadap wawasan atau landasan kependidikan. Aziz (2015: 177) mengungkapkan bahwa guru harus memiliki seperangkat pengetahuan secara filosofis, historis, yuridis, prinsip-prinsip serta pentingnya pendidikan seks bagi anak berkebutuhan khusus. Berdasarkan hasil penelitian, guru pengampu menerapkan hal tersebut. Guru mengetahui gambaran umum dari landasan filsofis, yuridis, dan pedagogis dalam pendidikan seksual anak autis usia remaja; namun landasan tersebut tidak menjadi perhatian utama. Hal ini dikarenakan guru lebih mengacu pada kemampuan belajar anak autis usia remaja dan landasan tersebut tidak berpengaruh secara dominan.

Guru juga memahami pentingnya pendidikan seksual bagi anak autis usia remaja, yaitu mengarahkan anak autis untuk berperilaku sesuai fisiknya yang berkembang, norma masyarakat yang berlaku dan tidak melakukan perilaku seksual menyimpang yang membahayakan dirinya sendiri atau orang lain. Hal ini sesuai dengan tujuan pendidikan seksual yang disampaikan oleh Roqib (2008: 3) bahwa pendidikan seksual dimungkinkan dapat meluruskan pemahaman dan perilaku seksual sehingga bisa lebih positif. Guru profesional juga memiliki wawasan tentang teori pembelajaran, sehingga mampu diterapkan sesuai peserta didiknya. Hasil penelitian menunjukkan bahwa guru menerapkan teori pembelajaran dalam proses pendidikan seksual, dimana guru lebih mengacu pada teori pembelajaran perilaku atau behavior. Hal ini sesuai dengan pendapat Danim (2010: 25) yang menyatakan bahwa guru perlu menerapkan teori belajar dan pembelajaran dalam kegiatan belajar. Penerapan teori behavior diketahui dengan adanya konsekuensi perilaku yaitu punishment dan reward dan pembuatan sub-sub perilaku (task analysis) dalam merancang target pencapaian anak. Hal ini sesuai pendapat Dahar (1996: 25) bahwa prinsip dalam teori belajar perilaku adalah adanya konsekuensi-konsekuensi yang sifatnya memperkuat perilaku dan melemahkan perilaku, konsekuensi yang segera diberikan setelah adanya perilaku lebih mempengaruhi dibanding konsekuensi yang lambat datangnya, dan pembentukan perilaku dengan mengajarkan keterampilan-keterampilan baru dalam mendekati perilaku yang diinginkan.

Danim (2010: 25) menjelaskan bahwa guru harus mampu untuk menentukan strategi pembelajaran berdasarkan karakteristik peserta didik, kompetensi yang ingin dicapai, dan materi ajar. Hal ini diterapkan guru dengan merancang strategi sesuai kemampuan belajar anak autis usia remaja yang masih terbatas, sehingga pembelajaran seksual sebatas materi identifikasi kebutuhan dan kebersihan diri. Adapun mengenai kompetensi yang ingin dicapai dan materi ajar, guru memodifikasi kurikulum yang ditetapkan pemerintah sesuai kemampuan anak autis usia remaja.

Aspek kedua dalam kompetensi pedagogis guru adalah pemahaman terhadap peserta didik. Guru anak autis juga seharusnya memberikan perhatian secara personal kepada peserta didiknya, sehingga tujuan pembelajaran lebih tepat sasaran. Hasil penelitian mengungkapkan bahwa guru pengampu memahami karakter peserta didik berdasarkan fisik, intelektual, dan sosial emosional anak autis usia remaja dengan melakukan pengamatan sehari-hari. Koller (2000: 127) menyampaikan bahwa individu autis mengalami perkembangan fisik dan seksual sesuai dengan tahap perkembangan pada umumnya. Guru mengidentifikasi kondisi fisik anak autis usia remaja, seperti mengetahui bahwa peserta didiknya pernah mimpi basah, mulai tumbuh rambut di sekitar kemaluan dan ketiak, dan suara yang membesar, seperti remaja umumnya. 


\title{
J PK (J urnal Pendidikan Khusus), 14 (2), 2018 - 94
}

\author{
Anis Tuing Isti Nur Syarifah
}

Guru pengampu juga memahami tentang intelektual dan sosial emosional anak autis usia remaja melalui hasil asesmen awal anak, keterangan dari orangtua, hasil evaluasi pembelajaran, dan pengamatan dalam pembelajaran sehari-hari. Kemampuan guru tersebut sesuai dengan yang dijelaskan oleh Winarno (2012: 71), bahwa seorang guru dapat dikatakan telah memahami peserta didik ketika dapat memahami peserta didik berdasarkan tingkat fisik, intelektual, sosial, emosional, moral, dan latar belakang sosial budaya.

Winarno (2012: 71) menjelaskan bahwa guru perlu mengidentifikasi karakter belajar peserta didik. Guru pengampu mengidentifikasi karakter belajar anak autis melalui informasi dari guru pengampu anak sebelumnya, pengamatan sehari-hari, dan hasil asesmen. Hasil penelitian juga mengungkapkan bahwa guru memfasilitasi anak autis usia remaja belajar tentang seksualitas sama halnya dengan anak remaja pada umumnya, namun tetap mempertimbangkan tingkat kemampuan belajarnya. Hal ini sesuai penjelasan Winarno (2012: 71), bahwa guru harus mampu memastikan bahwa semua peserta didik mendapatkan kesempatan yang sama untuk berpartisipasi aktif dalam kegiatan pembelajaran. Guru juga memfasilitasi anak autis untuk mempelajari seksualitas secara lebih luas dalam masyarakat yang lebih luas melalui kegiatan sosialiasi atau jalan-jalan ke tempat umum. Hal ini sesuai penjelasan UNESCO (2001: 10) tentang persamaan dalam pendidikan inklusi, bahwa pembelajaran terhadap peserta didik tidak hanya di sekolah. Anak juga belajar melalui keluarga, kontak dengan teman, dan partisipasi dalam bermacam-macam aktivitas yang ada dalam komunitas.

Winarno (2012: 71) menjelaskan bahwa dalam memahami peserta didik guru perlu mengetahui dan mengatasi kekurangan peserta didik serta mengidentifikasi bekal ajar awal peserta didik. Hal ini diterapkan oleh guru dengan mengetahui kesulitan belajar yang dialami oleh peserta didik melalui pengamatan dalam kegiatan pembelajaran, hasil asesmen, dan evaluasi pembelajaran sebelumnya. Langkah yang diambil guru untuk mengatasi kesulitasn tersebut dengan segera memberikan bantuan berupa pengulangan instruksi, pemberian contoh, bantuan isyarat, dan bimbingan fisik.

Hal lainnya yang sesuai dengan pernyataan Winarno tersebut yaitu guru pengampu mengidentifikasi bekal ajar awal anak autis usia remaja melalui hasil asesmen dan pengamatan seharihari. Dari sumber informasi tersebut, dapat diketahui tingkat pemahaman anak sebelumnya mengenai materi seksualitas.

Aspek selanjutnya yaitu pengembangan kurikulum dan perancangan pembelajaran. Mulyasa (2007: 100-102) menjelaskan bahwa terdapat beberapa hal yang perlu dilakukan dalam perancangan pembelajaran, yaitu identifikasi kebutuhan, identifikasi kompetensi, dan penyusunan program pembelajaran. Berdasarkan hasil penelitian, guru pengampu melakukan identifikasi kebutuhan belajar anak dalam pembelajaran seksualitas. Guru merancang topik-topik tertentu untuk mengetahui kemampuan dan kebutuhan belajar seksual anak autis secara lebih rinci dan jelas. Menurut NCSE (2013: 25), asesmen dilakukan berkelanjutan dan membuat siklus berupa asesmen, perencanaan, pelaksanaan pembelajaran, dan asesmen kembali. Hal ini diterapkan guru, yaitu asesmen tidak hanya dilakukan di awal saat anak mendaftar sekolah, namun dilakukan kembali setiap akhir semester dengan melalui refleksi dari analisis hasil pembelajaran.

Hasil penelitian mengungkapkan bahwa identifikasi kebutuhan belajar dilaksanakan tim guru yang dibentuk dari pihak sekolah. Pihak lainnya di luar tim guru, berpartisipasi secara tidak langsung dengan memberikan informasi tentang kondisi anak autis. Hal ini sesuai dengan yang dijelaskan Haryanto (2007: 32), bahwa asesmen dilakukan oleh tim multidisiplin yang dapat terdiri dari guru dan tenaga kependidikan lainnya, tenaga medis, psikolog, orangtua, dan tenaga terkait lainnya.

Tahap selanjutnya adalah identifikasi kompetensi. Menurut Mulyasa (2007: 101), kompetensi yang harus dipelajari dan dimiliki peserta didik perlu dinyatakan sedemikian rupa agar dapat dinilai, sebagai wujud hasil belajar yang mengacu pada pengalaman langsung. Pendapat tersebut diterapkan oleh guru, yaitu guru menentukan kompetensi berdasarkan kemampuan dan keterbatasan belajar anak autis. Kompetensi tersebut kemudian dibuat dalam rincian keterampilan tertentu.

Winarno (2012: 73) menjelaskan bahwa penyusunan program pembelajaran terdiri dari menyusun silabus yang sesuai dengan kurikulum, merancang rencana pembelajaran (RPP) yang sesuai dengan silabus, dan memilih materi pembelajaran. Hasil penelitian menjelaskan bahwa guru pengampu menyusun silabus disesuaikan dengan kurikulum yang telah dimodifikasi dan disesuaikan dengan kondisi dan tingkat kemampuan belajar peserta didiknya. Guru juga menyusun rencana pembelajaran (RPP) sesuai dengan silabus yang dibuat. 


\title{
J PK (J urnal Pendidikan Khusus), 14 (2), 2018 - 95
}

\author{
Anis Tuing Isti Nur Syarifah
}

Rancangan pembelajaran perlu disusun dengan memperhatikan format yang ada. Winarno (2012: 73) menyampaikan bahwa dalam RPP terdiri dari kompetensi dasar, materi standar, metode dan teknik, media dan sumber belajar, waktu belajar, dan daya dukung. Adapun RPP yang dirancang oleh guru memuat komponen-komponen tersebut yaitu KI-KD, indikator, tujuan pembelajaran, media dan sumber belajar, materi pembelajaran, metode, langkah pembelajaran, dan rancangan penilaian.

Guru pengampu menentukan materi pembelajaran seksual berdasarkan beberapa pertimbangan, khususnya berdasarkan tingkat kemampuan anak. Winarno (2012: 73) menjelaskan bahwa materi pembelajaran hendaknya sesuai dengan tujuan pembelajaran, tepat dan mutakhir/terkini, sesuai usia dan tingkat kemampuan peserta didik, dapat dilaksanakan di kelas, dan sesuai konteks kehidupan sehari-hari. Dalam pembelajaran seksual, guru menentukan materi identifikasi anggota tubuh dan kebersihan diri, dan materi tersebut memenuhi kriteria-kriteria tersebut. Pertama, bersifat terkini karena selalu dibutuhkan dan sesuai perkembangan zaman. Kedua, sesuai usia dan kemampuan anak autis, dimana kemampuan peserta didik guru masih sangat terbatas dan belum mengenal dirinya dengan baik dan anak diajarkan untuk merawat alat-alat vitalnya yang sudah berkembang. Ketiga, dapat dilaksanakan di kelas dan berbagai setting pembelajaran. Keempat, sesuai dengan konteks kehidupan sehari-hari yaitu materi ini adalah hal dasar yang perlu dikuasai manusia untuk kemandirian hidupnya.

Materi yang telah disusun oleh guru sesuai dengan pernyataan Travers \& Tincani (2010: 87), bahwa materi pertama dan dasar dalam pendidikan seksual anak autis adalah body awareness (kesadaran terhadap tubuhnya sendiri). Telah diketahui bahwa anak belum mampu mengurus diri sendiri secara mandiri, sehingga materi ini masih diberikan sebelum mempelajari materi lainnya seperti membina hubungan sosial, penyakit seksual menular, dan hubungan intim dengan orang lain.

Adapun dalam aspek pelaksanaan pembelajaran yang mendidik dan dialogis, pelaksanaan pembelajaran sendiri menjadi inti dari pendidikan seksual. Berdasarkan hasil penelitian, guru pengampu melaksanakan pembelajaran seksual tidak sepenuhnya sesuai dengan rancangan pembelajaran yang telah dibuat, karena kondisi anak autis yang mudah berubah. Namun, ketidaksesuaian tersebut sebatas hal yang bersifat teknis, seperti waktu pelaksanaan, langkah pembelajaran, serta teknis penerapan metode dan media. Winarno (2012: 74) menjelaskan bahwa salah satu indikator guru mampu melaksanakan pembelajaran dengan baik adalah guru melaksanakan pembelajaran sesuai dengan rancangan yang telah disusun lengkap. Oleh karena itu, dapat diketahui bahwa guru melaksanakan pembelajaran sesuai rancangan dengan menyesuaikan kondisi anak saat itu.

Guru pengampu menyampaikan materi sesuai dengan tingkat kemampuan belajar anak autis usia remaja dan disesuaikan dengan konteks kehidupan sehari-hari; sehingga materi dapat diaplikasikan dalam rutinitas anak autis. Materi juga disampaikan sesuai dengan usia anak autis, dimana guru memberikan informasi-informasi dasar dan umum tentang tingkat perkembangan fisik anak saat ini. Hal ini sesuai Winarno (2012: 74) bahwa perlu mengomunikasikan informasi baru sesuai dengan usia dan tingkat kemampuan belajar peserta didik, serta melaksanakan kegiatan pembelajaran sesuai dengan isi kurikulum dan mengaitkannya dengan konteks kehidupan sehari-hari.

Menurut Winarno (2012: 74), guru seharusnya melaksanakan pembelajaran yang bertujuan untuk membantu proses belajar peserta didik, bukan menguji. Hal ini diterapkan guru pengampu, dimana guru merancang pembelajaran yang berfungsi untuk membantu peserta didiknya dapat berperilaku seksual sesuai harapan guru. Guru melakukan pembelajaran dengan variasi metode dan media, pengenalan anak terhadap perkembangan fisiknya dan konsekuensinya; serta pemberian materi seksualitas dari yang paling sederhana. Bantuan lain yang diberikan yaitu saat anak mengalami kesulitan belajar.

Winarno (2012: 74) menyatakan bahwa guru dituntut menyikapi kesalahan peserta didik sebagai tahapan proses pembelajaran, bukan semata-mata kesalahan yang harus dikoreksi. Hasil penelitian mengungkapkan bahwa guru bersikap bijak terhadap kesalahan yang dilakukan oleh anak, khususnya saat anak melakukan perilaku seksual yang tidak sesuai. Guru memberikan teguran tegas (kadang diiringi dengan teguran fisik secara pelan), teguran berulang, meminta anak untuk mandi (untuk kasus onani), dan memperbanyak aktivitas belajar anak. Hasil penelitian juga menjelaskan bahwa guru melakukan pembelajaran seksual secara bervariasi yang disesuaikan dengan usia dan kemampuan anak autis. Hal ini sesuai penjelasan Winarno (2012: 74) bahwa guru perlu melakukan pembelajaran secara bervariasi dengan waktu yang cukup, serta sesuai dengan usia dan kemampuan belajar peserta didik. 


\title{
J PK (J urnal Pendidikan Khusus), 14 (2), 2018 - 96
}

\author{
Anis Tuing Isti Nur Syarifah
}

Variasi pembelajaran yang dilakukan yaitu dalam pengunaan media dan metode, tempat pembelajaran, serta pemberian materi pembelajaran yang beragam.

Winarno juga menjelaskan (2012: 74) bahwa guru seyogyanya mampu mengelola kelas dengan efektif tanpa mendominasi atau sibuk dengan kegiatannya sendiri. Hal ini dilakukan guru, dimana guru fokus melaksanakan pembelajaran dan tidak melakukan kesibukan lain di luar kepentingan pembelajaran seksual.

Guru juga perlu melibatkan anak secara aktif dalam pembelajaran. Dalam aspek ini, salah satu indikator yang diungkapkan oleh Winarno (2012: 74) adalah guru mampu memberikan kesempatan pada peserta didik untuk berperan aktif dalam pembelajaran. Adapun dalam hasil penelitian, diketahui bahwa guru melibatkan anak autis secara aktif dalam pembelajaran seksual dengan cara membangun pembelajaran yang menyenangkan dengan variasi metode dan media. Selain itu, guru banyak memberikan intruksi-intruksi dalam pembelajaran dimana setiap intruksi menuntut anak autis untuk memberikan respon secara aktif.

Adapun dalam aspek pemanfaatan teknologi pembelajaran, guru pengampu menggunakan berbagai media dalam pembelajaran seksual. Guru menggunakan media sebagai alat bantu belajar agar materi lebih mudah dipahami. Media yang digunakan yaitu media kartu, video, dan alat-alat nyata yang digunakan dalam kegiatan praktek. Hal ini sesuai yang diungkapkan oleh Falahudin (2014: 110) bahwa media meliputi alat bantu guru dalam mengajar serta sarana pembawa pesan dari sumber belajar ke penerima pesan (peserta didik).

Namun di sisi lain, guru pengampu belum memanfaatkan internet sebagai sumber belajar dalam pendidikan seksual untuk anak autis usia remaja. Internet sebatas membantu dalam komunikasi guru dengan pihak di luar sekolah. Hal ini dikarenakan salah satunya adalah penggunaan media benda nyata dirasa masih mencukupi kebutuhan pembelajaran seksual. Padahal, Mulyasa (2007: 106) menjelaskan bahwa guru dituntut untuk memiliki kompetensi dalam pemanfaatan teknologi pembelajaran, terutama internet; dalam pembelajaran.

Aspek selanjutnya adalah evaluasi hasil belajar. Hasil penelitian menjelaskan bahwa guru pengampu menyusun alat/instrumen penilaian dalam melakukan evaluasi terhadap kemampuan anak autis usia remaja dan pengukuran pencapaian tujuan pembelajaran dibuat dalam indikator dan skala penilaian tertentu; sehingga didapatkan data evaluasi yang valid dan jelas. Hal ini sesuai dengan yang dijelaskan oleh Winarno (2012: 76), bahwa guru harus mampu untuk menyusun alat penilaian yang sesuai dengan tujuan pembelajaran untuk mencapai kompetensi tertentu.

Winarno (2012: 76) juga menjelaskan bahwa salah satu indikator yang perlu dikuasai guru dalam evaluasi hasil belajar adalah melaksanakan penilaian dengan berbagai teknik dan jenis penilaian. Hal ini diterapkan guru dengan melakukan penilaian melalui pengamatan kegiatan seharihari dan kegiatan praktek/ unjuk kerja. Evaluasi pembelajaran dilakukan setiap hari dan dirangkum dalam laporan khusus setiap tiga bulan sekali dan tiap akhir semester.

Berdasarkan hasil penelitian, guru melakukan analisis hasil penilaian berupa analisis deksriptif yang ditulis dalam narasi singkat sesuai indikator. Analisis tersebut memberikan gambaran kekuatan dan kelemahan anak autis usia remaja dalam penguasaan materi pembelajaran seksual. Hal ini sesuai dengan pernyataan Winarno (2012: 76), bahwa guru dituntut mampu menganalisis hasil penilaian untuk mengidentifikasi topik yang sulit sehingga diketahui kekuatan dan kelemahan peserta didik untuk keperluan remedial dan pengayaan. Hanya saja, kegiatan remedial dan pengayaan tidak dilaksanakan oleh guru, karena setiap kesulitan anak selalu diatasi langsung saat kegiatan pembelajaran berlangsung dan ketika anak usia remaja mampu memahami materi atau perilaku tersebut, guru akan langsung melatih anak agar mampu menguasai hal tersebut secara lebih baik.

Guru menjadikan hasil penilaian sebagai landasan utama dalam merancang pembelajaran selanjutnya dan menjadi pelengkap informasi ketika informasi dari guru pengampu anak sebelumnya kurang lengkap. Hal ini sesuai penjelasan Winarno (2012: 76) bahwa guru harus mampu memanfaatkan hasil penilaian sebagai bahan penyusunan rancangan pembelajaran selanjutnya.

Aspek terakhir adalah pengembangan potensi peserta didik, yang kemudian dikembangkan peneliti menjadi pengembangan perilaku seksual pada anak autis usia remaja. Guru anak autis usia remaja perlu melakukan berbagai cara agar perilaku yang sudah dipahami anak autis dapat bertahan lama dan menjadi kebiasaan baik anak autis usia remaja. Pengembangan perilaku dapat diketahui melalui analisis hasil pembelajaran. Menurut Winarno (2012: 75), guru dituntut untuk menganalisis 


\title{
JPK (J urnal Pendidikan Khusus), 14 (2), 2018 - 97
}

\author{
Anis Tuing Isti Nur Syarifah
}

hasil belajar untuk mengetahui tingkat kemajuan masing-masing peserta didik. Guru pengampu telah melakukan analisis hasil penilaian untuk mengetahui tingkat kemajuan pemahaman dan perilaku seksual anak autis usia remaja terhadap tujuan pembelajaran yang telah dibuat.

Guru pengampu juga mengidentifikasi sejauh mana kemampuan anak autis dapat dikembangkan dalam pembelajaran seksual. Hal ini sesuai uraian Winarno (2012: 75) menjelaskan bahwa guru seharusnya mampu mengidentifikasi dengan benar tentang bakat, minat, potensi, dan kesulitan belajar masing-masing peserta didik.

Guru memfasilitasi pembelajaran seksual anak autis sesuai dengan karakter anak, daya tangkap anak terhadap pembelajaran, dan kondisi emosi peserta didik saat itu. Guru memfasilitasi anak autis dengan variasi metode dan media pembelajaran. Hal ini sesuai pendapat Winarno (2012: 75), bahwa guru seharusnya mampu memberikan kesempatan belajar kepada peserta didik sesuai dengan cara belajar masing-masing.

Winarno (2012: 75) menyampaikan bahwa guru secara aktif perlu membantu peserta didik dalam proses pembelajaran dengan memberikan perhatian kepada setiap individu. Hasil penelitian menjelaskan bahwa guru berusaha memberikan perhatian kepada setiap anak autis usia remaja dengan cara pengamatan terhadap perkembangan dalam pembelajaran seksual, melibatkan anak secara aktif dalam pembelajaran, dan segera memberikan bantuan saat anak mengalami kesulitan dalam mengerjakan aktivitas tertentu seperti kebersihan diri.

Pengembangan perilaku seksual pada anak autis usia remaja dapat dilakukan ketika interaksi terbangun kuat antara guru dan anak autis usia remaja. Menurut Winarno (2012: 75), guru perlu memusatkan perhatian pada interaksi dengan peserta didik dan mendorongnya untuk memahami dan menggunakan informasi yang disampaikan. Guru berusaha membangun interaksi yang intens dan memberikan motivasi kepada peserta didiknya agar membiasakan perilaku yang tepat, yaitu dengan membuat pembelajaran menyenangkan, pengulangan intruksi pembelajaran, dan pemberian reward.

\section{SIMPULAN DAN SARAN}

\section{Simpulan}

Berdasarkan hasil penelitian dan pembahasan, dapat disimpulkan kompetensi pedagogis yang dimiliki guru dalam pembelajaran seksual anak autis usia remaja di SLB Fajar Nugraha Yogyakarta, yaitu:

1. Guru mengetahui landasan pendidikan seksual dan pentingnya pembelajaran seksual untuk anak autis. Guru juga menentukan strategi pembelajaran seksual sesuai kemampuan anak autis usia remaja.

2. Guru memahami anak autis usia remaja dari berbagai sisi, meliputi kondisi perkembangan fisik, intelektual, dan sosial emosi anak, cara belajar anak, bekal ajar awal yang dimiliki oleh anak, dan kesulitan yang dialami oleh anak autis usia remaja.

3. Guru mengidentifikasi kebutuhan belajar seksual anak secara berkelanjutan, merancang kompetensi dalam keterampilan-keterampilan tertentu untuk membentuk perilaku yang utuh, dan menyusun program pembelajaran seksual untuk anak autis usia remaja dalam bentuk silabus dan RPP .

4. Guru melaksanakan pembelajaran seksual pada anak autis usia remaja sesuai dengan kemampuan dan kondisi anak saat itu. Guru melaksanakan pembelajaran seksual menyenangkan dengan menggunakan variasi setting pembelajaran seperti di kelas, di ruang tengah sekolah, dan di kamar mandi. Selain itu, guru juga melakukan variasi metode dan media, seperti belajar dengan kegiatan praktek, pemberian instruksi untuk melakukan suatu perilaku, pengenalan anak secara langsung terhadap perubahan fisik dan konsekuensi perilakunya, pemberian materi pembelajaran yang beragam, serta penggunaan media kartu dan benda-benda nyata.

5. Pemanfaatan teknologi pembelajaran sudah dilakukan guru dalam pembelajaran seksual untuk anak autis usia remaja, namun pengunaan teknologi elektronik (seperti internet dan video) belum optimal.

6. Evaluasi pembelajaran seksual pada anak autis usia remaja dilakukan dengan menggunakan form penilaian yang terukur. Guru kemudian melakukan analisis terhadap hasil penilaian dengan analisis deksriptif dan dituliskan dalam laporan akhir. Analisis penilaian tersebut kemudian menjadi landasan guru dalam merumuskan program pembelajaran seksual selanjutnya. 
7. Guru melakukan pengembangan perilaku seksual yang diajarkan pada anak autis usia remaja dengan cara membiasakan perilaku secara lebih lanjut dalam kehidupan sehari-hari, memfasilitasi pembelajaran seksual sesuai karakter belajar masing-masing anak autis, memberikan perhatian kepada anak autis usia remaja, dan membangun interaksi yang intens karena hal tersebut dapat mendorong anak untuk dapat menguasai perilaku seksual yang sesuai tersebut.

\section{Implikasi}

Berdasarkan hasil penelitian, peneliti dapat menyampaikan implikasi dari penelitian ini terhadap berbagai pihak. Bagi guru, hasil penelitian ini dapat digunakan sebagai bahan evaluasi dan pengembangan diri dalam kompetensi pedagogis guru, khususnya dalam pembelajaran seksual. Bagi sekolah, hasil penelitian ini dapat digunakan sebagai pertimbangan dalam evaluasi kinerja guru dan pengembangan kompetensi pedagogis guru secara umum. Adapun bagi pemerintah, penelitian ini diharapkan dapat menjadi pertimbangan dan evaluasi pemerintah dalam penentuan kebijakan dan program yang terkait dengan pengembangan kompetensi pedagogis guru dalam pembelajaran seksual. Dan bagi peneliti, penelitian ini menjadi masukan dalam pengembangan kompetensi pedagogis sebagai calon guru anak berkebutuhan khusus.

\section{Saran}

Berdasarkan hasil penelitian, peneliti dapat menyampaikan saran sebagai berikut:

1. Bagi guru

Guru perlu mengembangkan kompetensi pedagogis guru lebih lanjut, baik yang telah dikuasai maupun yang belum dikuasai. Secara khusus, perlunya dibentuk tim asesmen yang tidak hanya terdiri dari guru namun juga pihak-pihak lain seperti dokter tumbuh kembang dan psikolog. Guru hendaknya mengoptimalkan penggunaan media elektronik dalam pembelajara seksual untuk anak autis.

2. Bagi sekolah

Sekolah diharapkan mengembangkan kompetensi pedagogis guru dengan mengaktifkan pendalaman mengenai visi misi sekolah dan pentingnya pendidikan seksual untuk anak autis, serta melakukan pemerataan guru untuk mengikuti diklat Kesehatan Reproduksi.

3. Bagi pemerintah

Pemerintah diharapkan mampu merancang kurikulum khusus tentang pembelajaran seksual untuk anak autis usia remaja dan meningkatkan frekuensi pengadaan diklat Kesehatan Reproduksi untuk guru anak autis.

4. Bagi peneliti

Peneliti selanjutnya hendaknya melakukan penelitian lebih lanjut dan mendalam mengenai setiap aspek dalam kompetensi pedagogis guru dalam pendidikan seksual untuk anak autis usia remaja.

\section{DAFTAR PUSTAKA}

American Psychiatric Association. (2013). Diagnostic and Statistical Manual of Mental Disorders: Fifth Edition (DSM-5). Arlington: American Psychiatric Publishing.

American Psychological Association. (2002). A Reference for Professionals Developing Adolescents. Washington DC: American Psychological Association.

Arikunto, S. (2005). Manajemen Penelitian. Jakarta: Rineka Cipta.

Ariyanti, T.S. (2011). Komunikasi Pendidikan Seksual untuk Remaja Autisme. Skripsi, tidak diterbitkan, Universitas Sebelas Maret, Surakarta.

Aziz, S. (2014). Pendidikan Seks Bagi Anak Berkebutuhan Khusus. Jurnal Kependidikan Vol. II No. 2, 182-204. . (2015). Pendidikan Seks Anak Berkebutuhan Khusus. Yogyakarta: Gava Media.

Dahar, R.W. (1996). Teori-Teori Belajar. Jakarta: Erlangga.

Dalyono, M. (2005). Psikologi Pendidikan. Jakarta: Rineka Cipta.

Danim, S. (2010). Profesionalisasi dan Etika Profesi Guru. Bandung: Alfabeta. 
Depdikbud. (2005). Peraturan Pemerintah Republik Indonesia Nomor 19 Tahun 2005 tentang Standar Nasional Pendidikan

. (2005). Undang- Undang Republik Indonesia Nomor 14 Tahun 2005, tentang Guru dan Dosen.

. (2007). Peraturan Menteri Pendidikan Nasional Nomor 16 Tahun 2007 tentang Standar Kualifikasi Akademik dan Kompetensi Guru . (2008). Peraturan Pemerintah RI, Nomor 74, Tahun 2008, tentang Guru.

Falahudin, I. (2014). Pemanfaatan Media dalam Pembelajaran. Jurnal Lingkar Widyaiswara, Vol. 1 No. 4, 104-117.

Fisher, C.M. \& Cummings, C.A. (2016). Assesing Teacher Confidence and Proficiency with Sexuality Education Standards: Implication for Professional Development. Pedagogy in Health Promotion, Vol. 2 No.2, 101-107

Hallahan, D.P., Kauffman, J.M., \& Pullen, P.C. (2009). Exceptional Learners: An Introduction to Special Education. New York: Pearson.

Haryanto. (2007). Diktat Bahan Kuliah: Pengantar Asesmen Anak Berkebutuhan Khusus. Yogyakarta: FIP UNY.

Henault, I. (2013). Sexual Education for Adolescents and Young Adults with An Autism Spectrum Disorder: Themes and Adapted Steps. Autism Advisor, Vol. I no. 65, 1-2.

Hosnan, M. (2014). Psikologi Perkembangan Peserta Didik: Kiat Sukses Pendidikan Anak dalam Era Modern. Bogor: PT Ghalia Indonesia.

Hurlock, E.B. (1980). Psikologi Perkembangan: Suatu Pendekatan Sepanjang Rentang Kehidupan. (Terjemahan Istiwidayanti dan Soedjarwo) Jakarta: Erlangga.

Ishartiwi. (2012). Kompetensi Guru Pendidikan Khusus dan Model Pengembangannya dalam Upaya Peningkatan Kualitas Generasi Bangsa Penyandang Difabel. Jurnal Pendidikan Khusus, Vol. IX No.1, 1-11.

Koller, R. (2000). Sexuality and Adolescents with Autism. Sexuality and Disability, Vol. 18 No. 2, 125-135.

Kunandar. (2007). Guru Profesional: Implementasi Kurikulum Tingkat Satuan Pendidikan (KTSP) dan Sukses dalam Sertifikasi Guru. Jakarta: Rajawali Press.

Margono, S. (2014). Metodologi Penelitian Pendidikan. Jakarta: PT Rineka Cipta

Martin, D.N. (2005). The Ever-Changing Social Perception of Autism Spectrum Disorders in the United States. Exploration, Vol. I No.2, 160-170.

Marwiyah, S. (2012). Peranan Guru dalam Meningkatkan Mutu Pendididikan. Ulul Albab, Vol. 14 No.1, 4- 64.

Moleong, L.J. (2007). Metodologi Penelitian Kualitatif. Bandung: PT Remaja Rosdakarya.

Muhson, A. (2004). Meningkatkan Profesionalisme Guru: Sebuah Harapan. Jurnal Ekonomi dan Pendidikan, Vol. 2 No. 1, 90-98

Mulyasa, E. (2007). Standar Kompetensi dan Sertifikasi Guru. Bandung: PT Remaja Rosdakarya.

Nadlah, I. (2011). Penerapan Media Pembelajaran Bervariasi dapat Meningkatkan Kualitas Pembelajaran Materi Saling Ketergantungan dalam Ekosistem pada Siswa Kelas VIID 
SMPN 40 Semarang. Jurnal Penelitian Pendidikan, Vol 28 No. 1, 48-53.

National Council for Special Education. (2013). Supporting Students with Special Educational Needs in School. Mill Street: NCSE.

Papalia, D.E., Old, S.W., \& Feldman, R.D. (2008). Human Development. (Terjemahan A.K. Anwar). Jakarta: Prenada Media Group.

Payong, M.R. (2011). Sertifikasi Profesi Guru: Konsep Dasar, Problematika, dan Implementasinya. Jakarta: PT Indeks.

Roqib, M. (2008). Pendidikan Seks pada Anak Usia Dini. Insania Vol. 13 No. 2, 271-286.

Sexuality Information and Education Council of the United States. (2004). Guidelines for Comprehensive Sexuality Education: $3^{\text {rd }}$ Edition. Missouri: Fulton Press.

(2010). National Tacher Preparation Standards for Sexuality Education. Diambil pada 13 Maret 2018, dari www.futureofsexed.org/teacherstandards.html.

Sugiyono. (2014). Metode Penelitian Pendidikan: Pendekatan Kuantitatif, Kualitatif, dan R \& D. Bandung: Alfabeta.

Sukmadinata, N.S. (2016). Metode Penelitian Pendidikan. Bandung: PT Remaja Rosdakarya.

Sullivan, A. \& Caterino, L.C. (2008). Addressing the Sexuality and Sex Education of Individuals with Autism Spectrum Disorders. Education and Treatment of Children, Vol. 31 No. 3, 381-394.

Timmerman, G. (2009). Teaching Skills and Personal Caharacteristics of Sex Education Teachers. Teaching and Teacher Education, Vol. 25 No. 1, 500-506

Travers, J. \& Tincani, M. (2010). Sexuality Education for Individuals with Autism Spectrum Disorders: Critical Issues and Decision Making Guidelines. Education and Training in Autism and Developmental Disabilities, Vol. 45 No.2, 28-293.

United Nations Educational, Scientific, and Cultural Organization. (2001). Understanding and Responding to Children's Needs in Inclusive Classroms. Paris: UNESCO.

Widoyoko, S.E.P. (2017). Teknik Penyusunan Instrumen Penelitian. Yogyakarta: Pustaka Pelajar.

Widyasti, F.T. (2009). Seksualitas Remaja Autis Pada Masa Puber. Skripsi, Tidak diterbitkan, Universitas Diponegoro, Semarang.

Wilczynski, S.M., Menousek, K, Hunter, M, \& Mudgal, D. (2007). Individualized Education Programs for Youth with Autism Spectrum Disorder. Psychology in the Schools, Vol. 44 No. 7, 653-666.

Winarno, S. (2012). Profesionalisme Guru dan Kompetensi Padegogik serta Manfaatnya bagi Pendidikan Karakter Siswa. Jurnal Pendidikan, Vol. 16 No. 2 67-82.

Wuryani, S.E. (2008). Pendidikan Seks Keluarga. Jakarta: PT Indeks.

Yuwono, J. (2012). Memahami Anak Autistik: Kajian Teoritik dan Empirik. Bandung: Alfabeta. 